\title{
Kanonizacja nowomęczenników okresu niewoli tureckiej w Kościele prawosławnym i ich znaczenie ${ }^{\star}$
}

\author{
Jarosław Charkiewicz \\ Warszawska Metropolia Prawosławna \\ Polska \\ jarek@cerkiew.pl
}

Jarosław Charkiewicz, Canonization of the new-martyrs of the Ottoman period in the Orthodox Church and their importance, Elpis, 17 2015: 43-51.

\begin{abstract}
Article is devoted to the issue of the canonization of the so-called new-martyrs of the Balkans in the Orthodox Church, the issue that has not been in the Polish language studied yet. It concerns the saints who died for Christ after the conquest of Constantinople by the Turks in 1453 . The considerations on the subject is preceded by a short introduction on the role of the martyrs in the Church. Article also refers to the issue of nomenclature, i.e. the definition of the term "new-martyr", and its appearance in Christianity. Nearly 300 of the new-martyrs of the period of Ottoman slavery are known by the name. This group includes people of different social groups: the hierarchy, the rulers, the monks, married priests and lay people. It is probably only a small part of people who have suffered the death during this period in defense of Orthodoxy. The researchers divided them into four groups, which, the author presents. Their cult for centuries was limited because of the fear of consequences from the Turkish authorities. Only part of them was canonized after 1821 , when as a result of uprising the independence of the Greece was proclaimed.

The article also contains a part in which the importance of the new-martyrs of the Ottoman period for the Orthodox Church and its faithful is explained. Their importance was emphasized already by their contemporaries. This importance is multi-faceted and refers to the role of the Church plays from its beginning by the martyrs.
\end{abstract}

Streszczenie: Artykuł poświęcony jest kwestii kanonizacji tzw. nowomęczenników bałkańskich w Kościele prawosławnym, która nie była dotychczas w języku polskim przedmiotem badań. Dotyczy on zatem świętych, którzy ponieśli śmierć za Chrystusa po zdobyciu Konstantynopola przez Turków w 1453 roku. Zasadnicze rozważania na ten temat poprzedza krótki wstęp dotyczący roli męczenników w Kościele. Artykuł odnosi się również do kwestii nazewnictwa, tj. zdefiniowania terminu „nowomęczennik” oraz jego pojawiania się w chrześcijaństwie.

Z imienia znanych jest blisko 300 nowomęczenników okresu niewoli tureckiej na Bałkanach, wśród których są osoby różnych grup społecznych: hierarchowie, władcy, mnisi, żonaci kapłani i osoby świeckie. Jest to zapewne jedynie nieduża część osób, które poniosły w tym okresie śmierć w obronie Prawosławia. Badacze dzielą ich na cztery grupy, które też autor omawia. Ich kult przez długie wieki miał ograniczony charakter ze względu na obawy przed konsekwencjami ze strony władz tureckich. Tylko część spośród nich została kanonizowana po 1821 r., gdy w wyniku powstania niepodległościowego Grecja odzyskała niepodległość.

W artykule znajduje się również omówienie kwestii znaczenia nowomęczenników okresu niewoli tureckiej dla Kościoła prawosławnego i wiernych. Znaczenie to podkreślali już im współcześni. Jest ono wielopłaszczyznowe i nawiązuje do roli jaką w Kościele od początków jego istnienia posiadali męczennicy.

Keywords: canonization, saints, Orthodox Church, martyrs, new-martyrs, Ottoman Empire

Słowa kluczowe: kanonizacja, święci, Kościół prawosławny, męczennicy, nowomęczennicy, Cesarstwo Osmańskie

Kwestia kanonizacji nowomęczenników w Kościele prawosławnym nie była dotychczas w języku polskim przedmiotem szerszych opracowań ${ }^{1}$. Do tej pory znajdowała się ona w sferze zainteresowań przede wszystkim zagranicznych historyków, a w mniejszym stopniu również teologów, przy czym głównie greckich, rosyjskich, serbskich i bułgarskich. O ile czytający tylko po polsku czytelnik, szczególnie prawosławny, może posiadać pewną wiedzę na temat nowomęczenników, którzy ponieśli śmierć za Chrystusa w Związku Radzieckim w okresie władzy komunistycznej (tylko w 2000 r. Sobór Biskupów zaliczył tam do grona świętych 1097 osób, w większości nowomęczenni-

\footnotetext{
Projekt został sfinansowany ze środków Narodowego Centrum Nauki przyznanych na podstawie decyzji numer DEC-2012/07/N/HS1/01570

Kwestię tę wzmiankowałem ogólnie w jednym ze swych opracowań: J. Charkiewicz, Kanonizacja świętych w prawosławiu, Warszawa 2014.
}

ków, a obecnie w Soborze Nowomęczenników i Wyznawców Kościoła Rosyjskiego znajduje się blisko 1800 osób; tym samym nowomęczennicy, którzy ponieśli męczeńską śmierć za Chrystusa w okresie władzy radzieckiej na terenach ówczesnego Związku Radzieckiego stanowią największą grupę nowomęczenników) ${ }^{2}$, to $\mathrm{z}$ pewnością znacznie mniejsza jest jego wiedza o innych nowomęczennikach Kościoła prawosławnego, choćby 222 nowomęczennikach chińskich, którzy ponieśli śmierć za wiarę w 1900 r. w okre-

\footnotetext{
Patrz m.in.: Деяние о соборном прославлении новомучеников и исповедников Российских ХХ века, [в:] Собрание документов Русской Православной Церкви, т. 2, ч. 1. Деятельность Русской Православной Церкви, Москва 2014, с. 47. Por. K. Leśniewski, Kanonizacja świętych w tradycji Rosyjskiego Kościoła Prawosławnego, „Roczniki Teologiczne. Teologia Ekumeniczna”, t. LV, z. 7, Lublin 2008, s. 96-97.
} 
sie powstania bokserów ${ }^{3}$ czy nowomęczennikach serbskich okresu II wojny światowej, zaliczonych do grona świętych przez Serbski Kościół Prawosławny w latach 1998-2005. (Nowomęczennikami można również nazwać św. męczenników Ziemi Chełmskiej i Podlaskiej, kanonizowanych przez Kościół prawosławny w Polsce w 2003 roku czy św. Maksyma Sandowicza, zaliczonego do grona świętych w 1992 roku.). Jak się wydaje, najmniej znani polskiemu czytelnikowi są nowomęczennicy, którzy ponieśli śmierć za wiarę w okresie niewoli tureckiej na Bałkanach.

Rozważania na temat kanonizacji nowomęczenników bałkańskich (tak ich umownie można nazwać) zakończę próbą określenia ich znaczenia dla Kościoła prawosławnego, poprzedzę zaś krótkim wstępem dotyczącym roli męczenników w Kościele. Odniosę się również do kwestii nazewnictwa, tj. zdefiniowania terminu "nowomęczennik” oraz jego pojawiania się w chrześcijaństwie.

W niezliczonym gronie zastępów świętych, którym Kościół prawosławny oddaje cześć, których prosi o wstawiennictwo przed Bogiem i których stawia wiernym za wzory do naśladowania, znajdują się m.in. męczennicy (gr. Ма́ tegorii świętości, a jednocześnie cieszących się największą czcią. W świadomości chrześcijan pierwszych wieków upowszechniła się nawet opinia, że dusze męczenników są jedynymi, które już teraz, przed nastaniem końca świata i Sądem Ostatecznym, znajdują się w niebie. Powszechnie wierzono, że męczeństwo gładzi wszystkie grzechy popełnione po chrzcie, a zatem, stanowi jakby drugą (po chrzcie) pokutę, że przez swoją śmierć męczennicy uczestniczą w tajemnicy Śmierci i Zmartwychwstania Jezusa Chrystusa, a tym samym otrzymują odpuszczenie grzechów ${ }^{5}$. Św. Cyprian z Kartaginy prawdę tę zawarł obrazowo w kilku słowach: „W chrzcie wody otrzymuje się odpuszczenie grzechów, w chrzcie krwi - koronę cnót”. „Według najstarszej tradycji - pisze Paul Evdokimov - męczennik bezpośrednio wchodzi do Królestwa"7.

Od pierwszych wieków chrześcijaństwa męczeństwo postrzegane było w świetle życia Chrystusa. Traktowano je jako ofiarę najwyższą, która w sposób najczystszy urzeczywistniała miłość do Boga i bliźniego. Augustyn z Hippony w jednej ze swych mów mówił, że męczennicy „Nie bali się

\footnotetext{
Patrz m.in.: Прот. Димитрий Поздняев, Церковь на крови мучеников, http://www.chinese.orthodoxy.ru/russian/kb3/Martyrs2.htm [dostęp 3.01.2014], a w języku polskim: J. Charkiewicz, Prawosławie w Chinach, „Arche. Wiadomości Bractwa”, 1999, nr 3, s. 30-33.

4 Ich łączna liczba jest bliska 50. Patrz m.in.: J. Charkiewicz, Nowi męczennicy serbscy, „Cerkiewny Wiestnik”, 2001, nr 3, s. 38-44.

5 Męczennicy, oprac., wstęp i wybór tekstów E. Wipszycka i ks. M. Starowieyski, OŻ, t. 9, Kraków 1991, s. 126.

6 Św. Cyprian z Kartaginy, Do Fortunata wstęp, cyt. za: Św. Cyprian, Pisma, t. 1, Traktaty, przekł. i komentarz J. Czuj, Poznań 1937, s. 277.

P. Evdokimov, Prawosławie, przekł. ks. J. Klinger, Warszawa 1986, s. 27. Por. interesujące rozważania Nicholasa Contasa o poglądach Orygenesa na temat dusz świętych, które „idą do razu do raju”, jak też poglądach o tym późniejszych badaczy: N. Constas, „To Sleep, Perchance to Dream”: The Middle State of Souls in Patristic and Byzantine Literature, „Dumbarton Oaks Papers", 2001, nr 55, ed. A.-M. Talbot, s. 96-104.
}

ani umierać, ani cierpieć. Zwyciężył w nich Ten, kto w nich żył; [...] żyli nie dla siebie, lecz dla Niego"8, zaś w kazaniu na cześć męczenników Gerwazego i Protazego akcentował, że „Lepiej wspomagali Chrystusa martwi niż żywi. Dzisiaj wspomagają: dzisiaj głoszą: milczy język, brzmią czyny" Męczeństwo stawało się dopełnieniem chrześcijańskiego życia, najbardziej doskonałym naśladownictwem Chrystusa i wypełnieniem Jego przykazań. Realizowane w praktyce mogło być przy tym w pełnej jedności z Kościołem. „Nie może być męczennikiem, kto nie jest w Kościele”"10 - pisał św. Cyprian z Kartaginy.

To właśnie męczennikom św. Ojcowie poświęcili większość swoich homilii. „Ile mowa czynom, tyle nasze słowa ustępują nauce, którą dają ci Święci"11 - nauczał św. Jan Chryzostom, nazywając męczenników „duchowymi lekarzami”12 i „Chrystusowymi bohaterami”13, którzy „myśleli o dobrach z wysoka i - gardząc ziemskimi - szukali niebieskich"14, "porzuciwszy wszystkie rzeczy ziemskie, spoglądali oczyma wiary na Króla niebieskiego i na stojące przed Nimi zastępy aniołów”15. Tenże święty porównywał śmierć męczenników do chrztu, w którym umiera się dla świata ${ }^{16}$, a św. Cyprian z Kartaginy nazywał męczenników „prawdziwymi świadkami Ewangelii i prawdziwymi męczennikami Chrystusa"17. Używał też wobec nich wielu innych górnolotnych określeń ${ }^{18}$. Stawiał ich, jak i inni św. Ojcowie, za wzór do naśladowania dla chrześcijan: „Na was powinny wzorować się obyczaje, życie i czyny wszystkich"19 - pisał. Święci Ojcowie podkreślali równocześnie dwa ważne aspekty teologiczne męczeństwa. Po pierwsze, że dla chrześcijan męczennicy nadal żyją. „Męczennicy, którzy tak zasłużyli się dla naszego Kościoła i stali się jego upiększeniem, są żywi przed Bogiem" - nauczał św. Grzegorz z Nyssy ${ }^{20}$. Po drugie, że wychwalając męczenników, chwałę oddajemy samemu Chrystusowi: „Czcząc męczenników, którzy wycierpieli za Chrystusa, oddajemy chwałę Chrystusowi, Który wycierpiał za wszystkich"21 - nauczał św. Jan Chryzostom.

W pierwszych wiekach chrześcijaństwa męczeństwo

\footnotetext{
8 Św. Augustyn, Mowa 280,4, [w:] Św. Augustyn, Wybór mów (kazania świąteczne i okolicznościowe), tłum. J. Jaworski, wstęp i oprac. E. Stranula, Warszawa 1973, s. 185.

9 Augustyn z Hippony, Kazanie 286,3, przekł. R. Wiśniewski; cyt. za: Początki kultu relikwii na Zachodzie, dz.cyt., s. 121.

10 Św. Cyprian z Kartaginy, O jedności Kościoła katolickiego 14, [w:] Św. Cyprian. Pisma, t. 1: Traktaty, tł. i komentarz J. Czuj, Poznań 1937, s. 183. ${ }_{11}$ Św. Jan Chryzostom, Katecheza 7,2; cyt. za: Św. Jan Chryzostom, Katechezy chrzcielne, (Homilie katechetyczne do tych, którzy maja być oświeceni, oraz do neofitów), przeł. ks. W. Kania, wstęp i oprac. ks. M. Starowieyski, Lublin 1993, s. 97.

12 Św. Jan Chryzostom, Katecheza 7,5; cyt. za: tamże, s. 98.

13 Św. Jan Chryzostom, Katecheza 7,8; cyt. za: tamże, s. 99.

14 Św. Jan Chryzostom, Katecheza 7,17; cyt. za: tamże, s. 102.

15 Św. Jan Chryzostom, Katecheza 7,18; cyt. za: tamże, s. 102.

16 Św. Jan Chryzostom, Katecheza 7,20-23; cyt. za: tamże, s. 102.

17 Św. Cyprian z Kartaginy, List 37,4, [w:] Św. Cyprian, Listy, dz.cyt., s. 110 .

18 M. Wysocki, ks., Model doskonałego chrześcijanina w pismach św. Cypriana z Kartaginy, „Vox Patrum” 30 (2010), t. 55, s. 710.

19 Św. Cyprian z Kartaginy, List 13,3, [w:] Św. Cyprian, Listy, dz.cyt., s. 59.

20 Św. Grzegorz z Nyssy, Mowa pochwalna świętym 40 męczennikom, 3, cyt. za: Свт. Григорий Нисский, Творения, т. 8, Москва 1871, с. 253. ${ }_{21}$ Św. Jan Chryzostom, Homilia $w$ dniu pamięci męczenników, cyt. za: Свт. Иоанн Златоуст, Творения, т. 3, Санкт-Петербург 1897, с. 896.
} 
w największym stopniu sprzyjało rozwojowi Kościoła i było swojego rodzaju kontynuacją służby apostolskiej. Męczeństwo za Chrystusa i wiarę nie jest jednak fenomenem, który przeszedł do historii. Świadczą o tym choćby obecne prześladowania chrześcijan, w tym prawosławnych, w różnych częściach świata, aby wspomnieć choćby o Bliskim Wschodzie. Ta kategoria świętych pozostaje więc niezmiennie żywa i zapewne każdego dnia ubogaca się imionami kolejnych męczenników.

Jeśli dokonamy podziału wszystkich świętych na pewne typy czy kategorie ${ }^{22}$, to jedną $\mathrm{z}$ najważniejszych spośród nich w pewnością będą męczennicy. Męczenników, z kolei, podzielić można na cztery grupy: męczenników świeckich (gr. Мর́ będących hierarchami lub kapłanami /bez diakonów/ (gr.

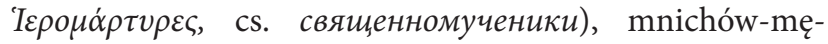

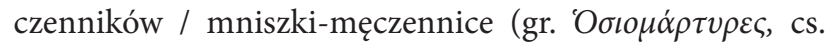
преподобномученики) ${ }^{23}$ oraz cierpiętników (gr. 'A $\theta \lambda$ фо́ ników Kościół prawosławny nadaje ponadto szczególne tytuły, jak: pierwszomęczennik, wielkomęczennik czy nowomęczennik.

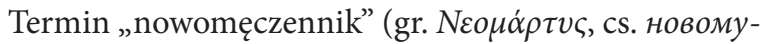
ченик) jest określeniem używanym w Prawosławiu wobec męczenników, którzy ponieśli śmierć z rąk wyznawców innych religii lub ateistów w czasach stosunkowo nieodległych. Pojawił się on na Bałkanach w XV w. w odniesieniu do męczenników, którzy ponieśli śmierć za wiarę po upadku Konstantynopola (1453), jednak w późniejszym czasie uległ rozszerzeniu. Kilka lat temu Patriarchat Konstantynopolitański zaliczył do grona świętych mnicha-męczennika Efrema Nowego (+1427), zamęczonego przez Turków jeszcze przed upadkiem Konstantynopola, który również tytułowany jest nowomęczennikiem. O przesunięciu nazewnictwa jeszcze dalej w przeszłość (ale i przyszłość) mogą też świadczyć choćby tytuły dwóch książek prezentujących żywoty nowomęczenników bałkańskich - „Synaksarionu Nowomęczenników. 1400-1900 po Chr.", który został opublikowany w Tesalonikach w 1989 roku $^{24}$, oraz wydanego w 2000 r. obszernego opracowania Nomikosa Vaporisa pt. „Witness for Christ. Orthodox Christian Neomartyrs of the Otoman Period 1437-1860"25.

Jak się wydaje, pierwszymi męczennikami prawosławnymi tytułowanymi „nowomęczennikami” byli dwaj bułgarscy święci: Jerzy Nowy (tzw. Kratowski) (+1515) i Mikołaj Nowy (tzw. Sofijski) (+1555), którzy ponieśli śmierć

\footnotetext{
22 J. Charkiewicz, Typologia świętych $w$ Kościele prawosławnym: próba systematyki, „Elpis”, 2009, XI (XXII), 19-20 (32-33), s. 323-380.

23 G. Skowrońska-Płaczynta proponuje zamienny szyk obu wyrazów, tj. „męczennik-mnich”, który również jest zrozumiały, jakkolwiek narusza chronologię, tj. „mnich-męczennik” najpierw został mnichem, a dopiero później poniósł męczeńską śmierć (podobnie jest z hierarchą-męczennikiem oraz kapłanem-męczennikiem); patrz: G. Skowrońska-Płaczynta, O kategoriach świętych..., dz.cyt., s. 182.

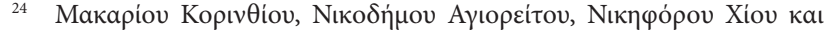

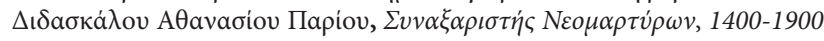

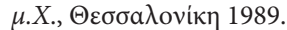

25 N. M. Vaporis, Witness for Christ. Orthodox Christian Neomartyrs of the Otoman Period 1437-1860, Crestwood 2000.
}

z rąk Turków za swoje przekonania religijne ${ }^{26}$. Termin „nowomęczennik" pojawił się w ich żywotach powstałych już w pierwszej połowie i w połowie XVI wieku ${ }^{27}$. Wcześniej przed Kościołem prawosławnym termin ten był jednak stosowany przez Kościoły orientalne - koptyjski i ormiański - wobec swoich świętych. Używano go w „Koptyjskim Synaksarionie” (XIII-XIV w.) m.in. wobec św. Jana Fanidżoita, zamęczonego przez wyznawców islamu w $1210 \mathrm{r}^{28}$, oraz od XIII w. w ormiańskich żywotach świętych, szczególnie tych, którzy ponieśli męczeńską śmierć za wiarę w XIV-XV w., gdy męczeństwo Ormian nabrało masowego charakte$\mathrm{ru}^{29}$.

Termin „nowomęczennik” w prawosławiu początkowo dotyczył męczenników, którzy ponieśli śmierć za wiarę w okresie niewoli tureckiej do greckiego powstania wyzwoleńczego 1821 roku. Z czasem - jak już powiedziałem - uległ on jednak rozszerzeniu o niedużą grupę męczenników sprzed 1453 roku. Okazało się jednak, że przypadki męczeństwa za Chrystusa w Kościele prawosławnym zaczęły mieć miejsce również po 1821 roku, a z biegiem lat nastąpiły kolejne fale męczeństwa za wiarę, by przywołać choćby czasy II wojny światowej na Bałkanach czy okres władzy komunistycznej w Związku Radzieckim. Dlatego też nie jest nadużyciem używanie tytułu „nowomęczennik” również wobec wszystkich męczenników, którzy oddali swoje życie za Chrystusa stosunkowo niedawno, aż po czasy współczesne $e^{30}$.

Wraz z upadkiem Konstantynopola sytuacja chrześcijan na terenach zajmowanych przez Turków stawała się coraz bardziej złożona. Nakładano na nich wciąż nowe ograniczenia i obciążenia. Aby uzmysłowić sobie, jak wyglądało życie chrześcijan pod niewolą turecką, zacytujmy fragment notatek archimandryty Tryfona. Pisze on: „Chrześcijanie nie mogli w sposób jawny wyznawać swojej wiary, nie mogli organizować procesji, uderzać w dzwony, gromadzić się w miejscach swojego zamieszkiwania na modlitwę, budować kaplic czy cerkwi, nosić broni czy takiego samego ubrania jak muzułmanie. Przemieszczać się mogli jedynie na ośle, przy czym przejeżdżając obok muzułmanina mieli obowiązek zejść na ziemię. Domy chrześcijan były specjalnie znakowane, aby uniknąć sytuacji, by jakiś ubogi muzułmanin przez przypadek nie prosił w nim o datek..."31.

\footnotetext{
26 A. Kawecka, Święci, świętość, błogosławieni w starych słowiańskich księgach liturgicznych i hagiograficznych, [w:] Święci i świętość u korzeni tworzenia się kultury narodów słowiańskich, red. W. Stępniak-Minczewa, Z.J. Kijas OFM Conv, Kraków 2000, s. 65.

27 К. Иванова, (энциклопедическая статья) Житейная литература, [в:] Православная энциклопедия, т. 19, Москва 2008, с. 301.

28 А.В. Муравьёв, (энциклопедическая статья) Житейная титература, [в:] Православная эниииклопедия, т. 19, Москва 2008, с. 292.

29 К. Тер-Давтян, (энциклопедическая статья) Житейная литература, [в:] Православная энииклопедия, т. 19, Москва 2008, с. 293.

30 Por. Константин Каварнос, Значение новых мучеников в жизни Православной Церкви, „Православная жизнь”, № 2 (590), февраль 1999 , с. 4.

31 Архимандрит Трифон, О положении христиан в мусульманском государстве согласно шариату, http://www.pravoslavie-i-islam.ru/ trifon.htm [dostęp 19.01.2015].
} 
Co jeszcze gorsze, chrześcijan zmuszano do przechodzenia na islam, przy czym często czyniono to również w stosunku do najmłodszych. Z chrześcijańskich domów Turcy zabierali dzieci w wieku 6-14 lat, aby usługiwały na dworze sułtana w Konstantynopolu lub Adrianopolu, a młodzieńców w wieku 14-20 lat przymusowo wcielano do tureckiego wojska. Według historyków, w tym celu w ciągu dwóch pierwszych wieków niewoli Turcy odebrali chrześcijanom od pół miliona do miliona dzieci ${ }^{32}$.

Wraz z nieustannie powiększającym się terytorium Cesarstwa Osmańskiego prześladowania chrześcijan zaczynały dotyczyć coraz szerszych grup ludności, coraz większej liczby narodów, które znalazły się pod panowaniem tureckim. Spośród wszystkich narodów głównym był, oczywiście, grecki, jednak nowomęczennicy byli również wśród innych narodów - przede wszystkim wśród Serbów, Bułgarów i Rumunów, ale również Turków (nawróconych na chrześcijaństwo), Albańczyków ${ }^{33}$, Rosjan ${ }^{34}$ czy Gruzinów ${ }^{35}$, którzy zamieszkiwali tereny tureckie lub znajdujące się pod turecką okupacją czy też znaleźli się na tych terenach $\mathrm{z}$ różnych powodów (np. wzięcia do niewoli, prowadzenia handlu itp.).

Z imienia znanych jest blisko 300 nowomęczenników tego okresu ${ }^{36}$, wśród których są osoby różnych grup społecznych: hierarchowie, władcy, mnisi, żonaci kapłani i osoby świeckie. O mnogości nowomęczenników okresu niewoli tureckiej może świadczyć obszerny (liczący kilkadziesiąt stron) list arcybiskupa Chersonu Eugeniusza (Bulgarisa/Vulgarisa) (+1806) do jansenisty Pierre Leclerca noszący tytuł „O świętych Kościoła prawosławnego po rozłamie i dokonujących się z nimi cudach”. Wymieniając na kilku stronach najbardziej znanych nowomęczenników XV-XVIII w., pisze on: „Oto tylko nieduża liczba niedawno objawionych wśród nas świętych [...], a jest jeszcze wielu innych" ${ }^{37}$. Nie ulega wątpliwości, że znani z imienia nowomęczennicy okresu niewoli stanowią jedynie wyci-

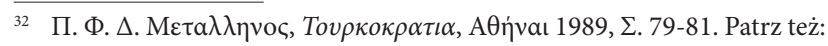
Будь верен до смерти. Судьбы Православия в Османской империи XVXX вв., Москва 2005, с. 10, oraz D. Constantelos, The 'Neomartyrs' as Evidence for Methods and Motives Leading to Conversion and Martyrdom in the Ottoman Empire, "Greek Orthodox Theological Review", 1978, No 23, p. 216-234.

33 Np. Chrestos Albańczyk (+1748), http://www.holytrinityorthodox. com/calendar/los/February/12-08.htm [19.01.2015].

34 Patrz głównie: Будь верен до смерти..., dz.cyt., N.M. Vaporis, Witness for Christ..., dz.cyt. W „Nowym Martyrologionie” św. Nikodem Hagioryta poza nowomęczennikami-Grekami, znalazły się również żywoty nowomęczenników Kościoła serbskiego, bułgarskiego, rumuńskiego, jak też rosyjskiego: męczennik Paweł $(+1683)$ i mnich-męczennik Konstanty (+1743), patrz np. http://www.saints.ru/p/Pave_russkii.html i http://www. saints.ru/k/8_svschmKonstantsiyaRusskogo.html [dostęp 18.01.2015], którzy będąc Rosjanami ponieśli śmierć za wiarę na terenie Cesarstwa Osmańskiego. Najbardziej znanym spośród nowomęczenników rosyjskich z okresu niewoli tureckiej na Bałkanach jest Jan Ruski $(+1730)$.

35 Mowa o męczenniku Antimie Iwerskim, metropolicie Wołoszczyzny, zamordowanym przez Turków w 1716 roku. Jego krótki żywot w języku polskim patrz: J. Charkiewicz, E. Kocój, Rumuńscy święci, Hajnówka 2012, s. $127-132$.

36 И.И. Соколов, Константинопольская церковь. Опыт исторического исследования, т. 1, Санкт-Петербург 1904, с. 22.

37 Суt. za: Константин Каварнос, Значение новых мучеников..., dz.cyt., c. 2. nek męczeństwa prawosławnych wiernych w Cesarstwie Osmańskim, o czym świadczyć mogą dane podawane przez greckie źródła: „od zdobycia Konstantynopola do ostatniej fazy greckiej wojny o niepodległość, osmańscy Turcy doprowadzili do śmierci 11 patriarchów ekumenicznych, blisko 100 biskupów, kilku tysięcy księży, diakonów i mnichów"38. Wykaz ten, jak widać, nie obejmuje osób świeckich, uwzględnienie których w znacznym stopniu podniosłoby dane statystyczne dotyczące rzeczywistej liczby nowomęczenników. Nie należy przy tym zapominać, że wielu prawosławnych ugięło się pod tureckim naciskiem, przyjmując islam ${ }^{39}$, a śmierć części nowomęczenników wynikała $\mathrm{z}$,ignorancji znajomości prawa islamskiego, zwyczajów, obyczajów, języka i tradycji”, co doprowadzało do stawiania chrześcijan przed tureckim sądem, przed którym mieli tylko jedną alternatywę: albo wyrzec się Chrystusa i przyjąć islam, albo ponieść śmierć ${ }^{40}$.

W okresie niewoli tureckiej (trwającym do 1821 r.) osoby, które oddały swe życie za Chrystusa, uznawane były przez Kościół za święte już z powodu samego faktu swojej męczeńskiej śmierci, bez względu na ich przynależność społeczną czy też to, czy związane były z ich osobami jakiekolwiek cudowne zdarzenia ( $w$ przypadku niemęczenników cuda pozostawały nieodzownym warunkiem kanonizacji). Kult nowomęczenników wśród wiernych zaczął pojawiać się samorzutnie, natomiast oficjalna reakcja Kościoła w tej kwestii musiała być bardziej złożona. Z reguły wobec nowomęczenników nie była przeprowadzana żadna oficjalna kanonizacja (w okresie niewoli tureckiej patriarchowie konstantynopolitańscy dokonywali jedynie nielicznych kanonizacji osób żyjących przed i po 1453 roku, których życie nie było związane z prześladowaniami ze strony Turków), a jeśli już nawet do nich dochodziło, to nie tytułowano ich „nowomęczennikami” czy nawet „męczennikami”, lecz po prostu „świętymi” (np. Filotea z Aten, +1589), aby tym samym uchronić Kościół przed dodatkowymi prześladowaniami ze strony okupanta. Pamięć nowomęczenników Kościół grecki pod panowaniem Turków w swych nabożeństwach zaczął obchodzić - jak pisze metropolita Kallistos Ware - „niezwłocznie”, chociaż „dla zmylenia uwagi Turków odbywało to się zwykle bez oficjal-

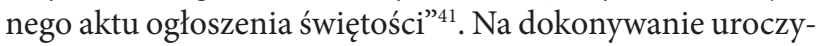
stych kanonizacji nie pozwalała sytuacja polityczna, co nie stało w sprzeczności z tym, że patriarchowie konstantynopolitańscy udzielali błogosławieństwa na oddawanie czci nowomęczennikom, sporządzanie na ich cześć nabożeństw

\footnotetext{
38 D. Constantelos, Altruistic Suicide or Altruistic Martyrdom? Christian Greek orthodox Neomartyrs: A Case Study, "Archives of Suicide Research", 2004, vol. 8, No 1, p. 60.

39 Analizując tego przyczyny Demetrios Constatelos wyszczególnia i omawia przyczyny natury politycznej, ekonomicznej i społecznej; tamże, s. 61-65.

40 Demetrios Constatelos wymienia 172 przypadki nowomęczenników, którzy nie wyparli się Chrystusa i ponieśli śmierć; tamże s. 65. Por. również: D. Constantelos, The 'Neomartyrs'..., dz.cyt. Turecki punkt widzenia tego problemu prezentuje np. Stanford J. Shaw, History of the Ottoman empire and modern Turkey, vols. 1-2, Cambridge 1976.

${ }_{41}$ K. Ware, Kościół prawosławny, przekł. ks. W. Misijuk, Białystok 2002, s. 283.
} 
oraz zanoszenie do nich prywatnych modlitw. Zasadniczo, zatem, oddawanie czci zamęczonym za wiarę pozostawiano indywidualnej gorliwości wiernych, czego głównym powodem była obawa Kościoła przed nowymi prześladowaniami ze strony władz tureckich.

Wśród nowomęczenników bałkańskich, którzy ponieśli śmierć z rąk Turków, badacze zwykle wyodrębniają cztery grupy ${ }^{42}$ :

(1) chrześcijanie, którzy z różnych pobudek wyrzekli się wiary chrześcijańskiej i przyjęli islam, lecz na znak pokuty przyjęli śmierć w imię Chrystusa, np. Michał ze Smyrny (+1772), Jerzy z Chios (+1907);

(2) tzw. "narodowi męczennicy” (cs. народные мученики) - chrześcijanie, którzy zginęli w wyniku represji politycznych ze strony władz tureckich, szczególnie w okresie powstania wyzwoleńczego 1821 roku, np. patriarcha konstantynopolitański Grzegorz V (+1821);

(3) muzułmanie, którzy przeszli na chrześcijaństwo i w związku z tym zostali straceni jako zdrajcy, np. Achmed Kalfas (+1682), Jan z Konicy (+1814), Konstantyn Agara$\operatorname{nin}(+1819)$;

(4) tzw. „samopowołani męczennicy” (cs. самопризванные мученики) chrześcijanie, którzy w porywie gorliwości i pragnieniu wycierpienia za Chrystusa, poddawali krytyce islam, konsekwencją czego było stawianie ich przed sądem i skazywanie na śmierć, o ile nie wyrzekną się swojej wiary, np. Dukas Krawiec (+1564), Mikołaj Sprzedawca $(+1672)$, Michał Ogrodnik $(+1770)^{43}$; do tej grypy należałoby również zaliczyć św. Antoniego Supraskiego ${ }^{44}$.

Świętość nowomęczenników ostatniej grupy była niekiedy podważana. Czynił tak np. znany grecki historyk metropolita Gedeon, który nazywał takich męczenników „pozbawionymi rozumu”, a ich nauczycieli czy inspiratorów „fanatykami”. Jednak zdecydowana większość osób, które oceniały takiego typu zachowania, uważała, że męczenników takich należy uważać za świętych. Takie poglądy wyrażali w swych dziełach m.in. św. Nikodem Hagioryta (+1809), św. Makary (Notara), metropolita Koryntu (+1805), czy św. Atanazy z Paros (+1813). Ostatni z nich napisał nawet traktat o jednoznacznym tytule: „O tym, że nowi męczennicy są świętymi i powinni być za takich uważani bez działań kanonizacyjnych Wielkiego Kościoła" ${ }^{35}$. Również patriarcha konstantynopolitański Grzegorz V wraz z soborem biskupów swojego Kościoła „uroczyście potwierdził powszechnie przyjętą opinię na temat tych męczenników jako o doskonałych męczennikach"46.

Istniał pewien „schemat zachowań” poprzedzający męczeństwo tej grupy nowomęczenników. Otóż, osoba, która zdecydowała się na męczeństwo za wiarę, musiała najpierw udać się do swojego ojca duchowego bądź innego doświad-

\footnotetext{
42 Por. nieco inną klasyfikację: Будь верен до смерти..., dz.cyt., s. 14

43 Por. H. Delehaye, Greek Neo-Martyrs, [w:] Melanges d'hagiographie grecque et latine, Bruxelles 1966, p. 246-255.

44 A. i M. Mironowicz, Święty Antoni Supraski, Białystok 2014.

45 Е. В. Ткачов, (энциклопедическая статья) Канонизация, [в:] Православная энииклопедия, т. 30, Москва 2012, с. 283.

46 Е. Е. Голубинский, История канонизации святьх Русской Церкви, Москва 1903, с. 27. Por. Е.В. Ткачов, (энциклопедическая статья) Канонизация, dz.cyt., с. 283.
}

czonego kapłana, przystąpić do sakramentu spowiedzi i ujawnić przed nim swój zamiar. Otrzymywała wówczas z rąk spowiednika sakrament namaszczenia świętym olejem, po czym udawała się w ustronne miejsce, gdzie, poszcząc i modląc się, upraszała Boga o wybaczenie grzechów i duchowe umocnienie wytrwania w podjętym zamiarze. Przygotowanie to kończyło przyjęcie przez tę osobę św. Eucharystii. Następnie udawała się ona w jakieś publiczne miejsce muzułmanów i tam przed zebranymi ogłaszała, że wyznaje wiarę w Chrystusa, za którego pragnie przyjąć śmierć ${ }^{47}$. Wszystko kończyło się sądem i skazaniem takiej osoby na śmierć przez ścięcie mieczem.

Skomplikowana sytuacja związana z czcią oddawaną nowomęczennikom sprawiła, że gdy pod koniec XVIII w. w Grecji możliwe stało się gromadzenie dotyczących ich materiałów i próbowano usystematyzować wiadomości na ich temat, to w niewielu przypadkach możliwe było ustalenie inicjatorów kultu oraz tego, od kiedy miał on miejsce. Pracą tą zajmował się głównie ruch kolliwadów ${ }^{48}$, przede wszystkim zaś wspomniani święci: Nikodem Hagioryta, Makary Notara i Atanazy z Paros. W 1799 r. w Wenecji wydano „Nowy Martyrologion” ${ }^{49}$ autorstwa św. Nikodema, w którym znalazły się żywoty 86 nowomęczenników, żyjących w latach 1492-1794, jak też nabożeństwa na cześć części z nich ${ }^{50}$. Z kolei w „Nowym Limonarionie” (1819) ułożonym przez świętych Makarego, Atanazego z Paros i Nicefora z Chios (+1821), poza żywotami nowomęczenników, znalazły się nabożeństwa do wielu spośród nich.

Żywoty nowomęczenników i ich wykazy, które powstawały u schyłku XVIII i na początku XIX w. sporządzane były nie tylko z błogosławieństwa patriarchów konstantynopolitańskich Cyryla VI (1813-1818) i Grzegorza V (1797-1798, 1806-1808, 1818-1821), ale też przy ich udziale. Chociaż wówczas nie mogły temu jeszcze towarzyszyć uroczyste akty kanonizacyjne, to stanowiło to wyraźną zachętę do kierowania do tych świętych indywidualnych modlitw przez wier-

\footnotetext{
47 Будь верен до смерти..., dz.cyt., s. 14.

48 Patrz np. interesujący artykuł: Движение колливадов, http://www. pravoslavie.ru/archiv/kollibades.htm [dostęp 17.01.2015].

${ }_{49}$ W 1961 r. w Atenach ukazało się znacznie poszerzone trzecie wydanie tego martyrologionu. Zawarte w nim żywoty w przekładzie na język rosyjski ukazały się w dwóch pracach: Абонский патерик, или Жизнеописание святых, на Св. Абонской горе просиявших, Москва 1897, т. 2 (żywoty 16 nowomęczenników Atosu) oraz П.А. Соловьев, свящ., Христианские мученики, пострадавшие на Востоке со времени завоевания Константинополя турками, СПб. 1862 (żywoty 70 innych nowomęczenników). Wartym podkreślenia jest, że św. Nikodem jest również autorem m.in. napisanego bardzo przystępnym językiem trzytomowego Synaksarionu, zawierającego około 650 żywotów świętych, w którym wzmiankowanych zostało około 60 tys. świętych. Dzieło to napisał w ciągu zaledwie dwóch lat, a ukazało się ono również w Wenecji, już po jego śmierci w 1819 roku; Иеромонах Илия (Читтерио): Преподобный Никодим Святогорец - учитель духовной жизни и маяк Церкви.Иеромонах Илия (Читтерио): Преподобный Никодим Святогорец - учитель духовной жизни и маяк Церкви. Иеромонах Илия (Читтерио), Преподобный Никодим Святогореи - учитель духовной жизни и маяк Церкви, перевод Ирина Волкова, „Православная община” 2000, № 60, с. 88.

50 Por. interesujący artykuł: N. Vaporis, The Price of Faith: Some Reflections on Nicodemos Hagiorites and His Struggle against Islam, Together with a Translation of the 'Introduction' to His 'New Martyrologion', "Greek Orthodox Theological Review", 1978, No 23, p. 185-215.
} 
nych. W tym okresie św. Nikodem Hagioryta napisał szereg nabożeństw ku czci niektórych nowomęczenników, jak też nabożeństwo ku czci Soboru Świętych Nowomęczenników (w którym wymienionych zostało 88 świętych), którzy ponieśli śmierć po upadku Konstantynopola. Na początku XIX w. św. Nicefor w Chios napisał też tzw. nabożeństwo na cześć bezimiennego nowomęczennika ${ }^{51}$.

Po odzyskaniu niepodległości przez Grecję, w wyniku zwycięskiego powstania 1821 roku, w Kościele prawosławnym na tych terenach pojawiła się możliwość swobodnego wyrażania opinii o chrześcijanach, którzy stracili życie w okresie niewoli tureckiej. O ile wcześniej kwestia czci oddawanej nowomęczennikom pozostawała przede wszystkim kwestią prywatną wiernych, opierająca się na (zwykle nieoficjalne) błogosławieństwach ze strony patriarchy, które można byłoby nazwać „nieformalną kanonizacją”, to obecnie sytuacja uległa diametralnej zmianie. O ich kulcie i kanonizacji mogły mówić szerokie kręgi cerkiewne. $\mathrm{Z}$ czasem zaczęły też pojawiać się poważne opracowania naukowe, które mogły być pomocne przy kanonizacjach. W 1934 r. ukazało się pierwsze wydanie książki pt. „Nowomęczennicy" 52 autorstwa arcybiskupa Aten Chryzostoma I (Papadopoulosa), która zawiera nie tylko szereg informacji biograficznych na temat nowomęczenników, ale również cenne myśli dotyczące ich roli w prawosławiu. Praca ta zawiera żywoty 130 nowomęczenników z okresu od $1453 \mathrm{r}$. do połowy XIX wieku.

Duża fala zainteresowania nowomęczennikami, związana z 160. rocznicą odzyskania niepodległości, miała miejsce w Grecji w latach 80. i 90. XX wieku. Zorganizowano wówczas kilka konferencji naukowych poświęconych tej tematyce, ukazało się też szereg monografii poświęconych nowomęczennikom. W latach 80. XX w. dwóch wydań (1986 i 1989) doczekał się m.in. obszerny „Synaksarion Nowomęczenników", w którym znalazły się wcześniej publikowane żywoty oraz nowe materiały ${ }^{53}$. Interesujące wydają się zawarte w nim dane statystyczne. Synaksarion ten prezentuje żywoty nowomęczenników odpowiednio: z XV w. - 9, z XVI w. - 22, z XVII w. - 38, z XVIII w. - 50, a XIX w. - 58. Dane te mogłyby sugerować wzrost liczby męczenników w kolejnych wiekach, podczas gdy w rzeczywistości świadczą one bardziej o większej liczbie zachowanych informacji na temat tych, którzy żyli stosunkowo niedawno, w porównaniu z żyjącymi w początkowym okresie niewoli tureckiej ${ }^{54}$. Również w latach 80 . ukazał się przekład z języka greckiego na angielski książki pt. „New Martyrs on the Turkish Yoke", w której w układzie kalendarzowym (od stycznia do grudnia) prezentowane są żywoty około 100 nowomęczenników okresu niewoli tureckiej ${ }^{55}$. Również

\footnotetext{
51 Е.Е. Голубинский, История канонизации святых Русской Церкви, dz.cyt. c. 27. Por. Е.В. Ткачов, (энциклопедическая статья) Канонизация, dz.cyt., с. 281-282.

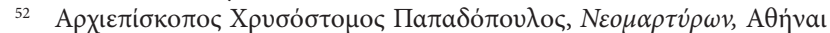
1970.

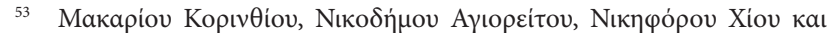

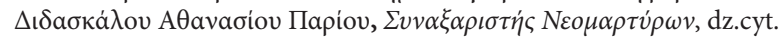

54 Por. Новомученики балканские, Москва 2000, s. 9.

55 New Martyrs on the Turkish Yoke, trans. by Leonidas J. Papadopoulos, Georgia Lizardos and others, Washington 1985.
}

w USA w 2000 r. ukazało się solidne opracowanie żywotów nowomęczenników w ujęciu chronologicznym autorstwa amerykańskiego duchownego Greka Nomikosa Vaporisa ${ }^{56}$. Zawiera ono około 200 biogramów.

Pomimo, jak się wydaje, znacznej liczby zgromadzonych materiałów na temat życia (a głównie jego końcowego etapu) nowomęczenników okresu niewoli tureckiej na Bałkanach, kwestia ich kanonizacji została do tej pory rozwiązana jedynie częściowo. Związane jest to, jak się wydaje, przede wszystkim z faktem, że siedziba Patriarchatu Konstantynopolitańskiego - Stambuł - znajduje się na terenie Turcji, a patriarcha konstantynopolitański zobowiązany jest do lojalności względem państwa tureckiego, którego musi też być obywatelem. Dlatego też, zdaniem rosyjskiego historyka Eugeniusza Tkaczowa (i nie sposób nie przyznać mu racji), „nadal otwarta pozostaje kwestia uroczystej ogólnokościelnej kanonizacji nowomęczenników, którzy świadczyli swoją wiarę w Chrystusa w okresie panowania osmańskiego"s7. Kult liturgiczny nowomęczenników czasów niewoli tureckiej odbywa się, zatem, w znacznym stopniu bez formalnego aktu kanonizacji, co jest dopuszczalne - jak pisze metropolita Kallistos Ware - „w wyjątkowych okolicznościach"58. Pamięć niektórych z nich obchodzona jest osobno, $\mathrm{z}$ reguły $\mathrm{w}$ rocznicę ich śmierci, a zbiorowo (soborowo) w trzecią niedzielę po Pięćdziesiątnicy.

Decyzją św. Synodu Patriarchatu Konstantynopolitańskiego kanonizowano do tej pory stosunkowo niewielu nowomęczenników, przy czym informacje na ten temat są $\mathrm{w}$ dużym stopniu nieusystematyzowane. $\mathrm{W}$ tym miejscu warto przypomnieć, że organem podejmującym decyzje w sprawie kanonizacji ogólnokościelnych w Patriarchacie Konstantynopolitańskim jest właśnie św. Synod. Do kompetencji patriarchy konstantynopolitańskiego należy zaś dokonywanie kanonizacji ogólnokościelnych wobec świętych lokalnych, tj. takich, którzy zostali zaliczeni do grona świętych lokalnych wcześniej, z błogosławieństwa patriarchy, a po inicjatywie miejscowego biskupa. Takie "podnoszenie rangi” świętego było popularne szczególnie w okresie między rokiem 1821 a II wojną światową. Po II wojnie światowej wzrosła z kolei liczba kanonizacji ogólnokościelnych dokonywanych przez św. Synod. Kanonizacje te dotyczyły przy tym zarówno świętych odległych czasów (XIV-XV w.), okresu nowomęczenników (poł. XV - pocz. XIX w.), jak i świętych żyjących w wieku XIX czy XX. Natomiast zgodnie ze statutem Greckiego Kościoła Prawosławnego (w którego jurysdykcji znajduje się znaczna część Grecji) kanonizacja ogólnokościelna odbywa się po uprzednim błogosławieństwie patriarchy konstantynopolitańskiego ${ }^{59}$.

Przechodząc do szczegółów, wymienić można imiona tych bałkańskich nowomęczenników, którzy doczekali

\footnotetext{
N.M. Vaporis, Witness for Christ..., dz.cyt.

57 Е.В Ткачов, (энциклопедическая статья) Канонизация..., dz.cyt., с. 283.

58 K. Ware, Kościół prawosławny, przekł. ks. W. Misijuk, Białystok 2002, s. 283.

59 Е.В Ткачов, (энциклопедическая статья) Канонизация..., dz.cyt., c. 283. Na temat obecności greckich nowomęczenników w kalendarzach kościelnych patrz: A. Rigo; N. Russel, Neomartyrs of the greek calendar, "Sobornost, incorporating Eastern Churches Review", 1983, No 5, p. 36-62.
} 
się oficjalnej kanonizacji ze strony Kościoła prawosławnego. W Patriarchacie Konstantynopolitańskim w 1839 r. kanonizowano męczennika Jerzego z Janiny $(+1838)(\mathrm{z}$ urodzenia Albańczyka); w 1921 r. męczennika-patriarchę konstantynopolitańskiego Grzegorza V (+1821); w 1961 r. równego apostołom mnicha-męczennika Kosmę z Etoli (+1779); w 1970 r. męczenników z Lesbos: ihumena Rafaela, diakona Mikołaja, dziewicy Ireny i innych $(+1463)$; w 1977 r. męczenników-krewnych Jerzego, Angelisa, Manuela i Mikołaja ze wsi Melambes na Krecie $(+1824)$; w 1985 r. męczenników Manuela, Teodora, Jerzego, Jana, Michała i Lamprosa z Samotraki (+1835), w 2000 r. Nowomęczenników Kreteńskich (+1821-1822); w 2003 r. 5 mnichów-męczenników (po dwóch Neofitow i Jonaszów oraz Parteniusza) żyjących w XVI-XVII w. na wyspie Lipsi; w 2011 r. (na prośbę Kościoła greckiego) mnicha-męczennika Efrema Nowego (+1427), który poniósł śmierć z rąk muzułmanów jeszcze przed upadkiem Konstantynopola, oraz 1241 bezimiennych męczenników z Naussy $(+1822)^{60}$.

Patriarcha antiocheński Makary III kanonizował męczennika Dawida z Aleppo (+1660) następnego dnia po jego śmierci z rąk Turków. Kolejna kanonizacja w Patriarchacie Antiocheńskim miała miejsce dopiero w 1993 r., a dotyczyła kapłana-męczennika Józefa z Damaszku $(+1860)^{61}$. Jeszcze jedna kanonizacja, już późniejszych nowomęczenników, w tym patriarchacie miała miejsce w 2008 r., kiedy do grona świętych zaliczono kapłanów-męczenników Haszków - ojca Mikołaja (+1917) i syna Habiba $(+1948)^{62}$. Z kolei Patriarchat Jerozolimski w 2009 r. dokonał kanonizacji archimandryty Filemona (Chasapisa) (+1979), który został bestialsko zamordowany przez fanatycznych Żydów ${ }^{63}$. On również tytułowany jest nowomęczennikiem.

Mówiąc na temat znaczenia nowomęczenników okresu niewoli tureckiej dla Kościoła prawosławnego i wiernych, zauważyć należy, że podkreślali ją już im współcześni. Szerzej pisali o tym szczególnie: arcybiskup Chersonu Eugeniusz (Bulgaris) we wspomnianym liście do Leclerca oraz św. Nikodem Hagioryta w „Nowym Martyrologionie”.

Pierwszy z nich w swym liście podkreśla, że Kościół prawosławny dzięki nowomęczennikom „wzrasta i jest wychwalany", jest przez nich „upiększany i czyni cuda" ${ }^{64}$. Drugi do swojego dzieła napisał obszerne wprowadzenie, w którym wymienia pięć powodów, dla których Bóg sprawił, że „nowomęczennicy objawili się w naszych czasach”. Zacytujmy je: „Po pierwsze, w celu odnowienia całej wiary prawosławnej. Po drugie, aby ludzie małej wiary nie mie-

\footnotetext{
60 Е.В Ткачов, (энциклопедическая статья) Канонизация..., dz.cyt., c. $283-286$

${ }^{61}$ Jego żywot patrz: Жития святых составленные на Святой Горе Абон. Синаксарь, т. VI, июль-август, Москва 2011, с. 143-144.

62 Архимандрит Фома (Петар), Священномученик Николай Хашех, перевела с арабского Надежда Семенова, http://www.pravoslavie.ru/ orthodoxchurches/41541.htm [dostęp 19.01.2015].

63 Е.В Ткачов, (энциклопедическая статья) Канонизация..., dz.cyt., c. 287.

64 Суt. za: Константин Каварнос, Значение новых мучеников..., dz.cyt., c. 2.
}

li usprawiedliwienia w dniu Sądu Ostatecznego (mowa o misyjnej roli, jaką nowomęczennicy odgrywają względem innowierców - przyp. J.Ch.). Po trzecie, aby męczennicy byli chwałą i upiększeniem Kościoła prawosławnego jak też świadectwem przeciwko heretykom i na ich hańbę. Po czwarte, aby służyli za przykład wyjątkowej cierpliwości dla wszystkich prawosławnych chrześcijan, cierpiących z powodu ciężkiego jarzma tyranii. I po piąte, aby inspirowali oni męstwo i stałość w sercach wszystkich chrześcijan, którzy są zmuszani uwarunkowaniami do przyjmowania męczeństwa, a szczególnie tych, którzy znajdowali się na progu odstępstwa od wiary prawosławnej, aby podążali za ich (tj. nowomęczenników - przyp. J.Ch.) przykładem" ${ }^{\text {"65 }}$. W dalszej części wprowadzenia św. Nikodem szczegółowo omawia wszystkie te aspekty, m.in. stawiając nowomęczenników na równi z męczennikami pierwszych wieków chrześcijaństwa. Nowomęczennicy przelewając swoją krew i czyniąc cuda, wg św. Nikodema, „odnawiają wiarę w Jezusa Chrystusa” i „rzeczywiście świadczą przed innowiercami, aby opamiętali się, gdy ujawniony zostanie ich główny cel - męczenie wiernych prawosławnych oraz [...], aby wyrzekli się swojej wiary"66. Nawiązując do św. Jana Chryzostoma, św. Nikodem pisze również, że „Człowiek nie staje się męczennikiem z powodu tego, że ścięto mu głowę, lecz wówczas gdy wyraża gotowość przyjęcia męczeństwa, nawet jeśli nie zmarł śmiercią męczeńską" ${ }^{67}$ (włącza tym samym wyznawców do męczenników).

Mówiąc o roli nowomęczenników dla prawosławia, warto również przytoczyć wypowiedź arcybiskupa Aten Chryzostoma I, kierującego Kościołem greckich w latach 1923-1938. Autor „Nowomęczenników”, pisząc o ich znaczeniu, podkreśla że: „Będąc pod niewolą turecką [...] Kościół walczył o zbawienie swych dzieci i umocnienie ich w wierze. $\mathrm{W}$ tej walce Kościoła prawosławnego ważne znaczenie mają nowomęczennicy. [...] Jak świecące słońca w nocy niewolnictwa, jak pewne kotwice w czasach smuty, o, wy, nowomęczennicy, zajaśnieliście we wszystkich zakątkach ziemi, rozpalając w wiernych miłość i umacniając serca tych, których wiara była chwiejna"68.

Istotnym uzupełnieniem wyżej wymienionych aspektów definiujących znaczenie nowomęczenników w prawosławiu są poświęcone temu zagadnieniu rozważania znanego współczesnego teologa schimnicha Constantina Cavarnosa (+2011). W wydanej w 1992 r. przez Rosyjski Kościół Prawosławny za Granicą książeczce pt. „The Significance of the New Martyrs in the Life of the Orthodox Church"69 do pięciu punktów św. Nikodema dodaje on trzy kolejne związane z rolą nowomęczenników. Mówi, po pierwsze, o roli, jaką pełnią ich święte relikwie, „uzdra-

\footnotetext{
65 Cyt. za: tamże, c. 4.

66 Иеромонах Илия (Читтерио), Преподобный Никодим Святогоpeu..., dz.cyt., c. 89.

67 Cyt. za: Константин Каварнос, Значение новых мучеников..., dz.cyt., c. 7.

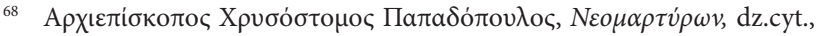
₹. 130-131.

69 Constantine Cavarnos, The Significance of the New Martyrs in the Life of the Orthodox Church, Center for Traditionalist Orthodox Studies, Etna 1992.
} 
wiające niedomagania ciała i duszy". Po drugie, akcentuje znaczenie nowomęczenników dla pisarzy i hymnografów cerkiewnych, dla których są oni inspiracją w tworzeniu utworów służących zbawieniu człowieka. Po trzecie - jak pisze - nowomęczennicy mają wpływ na „upiększenie Kościoła nowymi ikonami i nowymi świątyniami wznoszonymi na ich cześć"’o.

Tym samym, opierając się na przemyśleniach zaledwie trzech znawców kwestii nowomęczenników bałkańskich okresu niewoli tureckiej, dostrzegamy, jak istotną, chociaż, niestety, często przemilczaną czy niedocenianą rolę pełnili i pełnią nowomęczennicy w życiu Kościoła prawosławnego i nas samych, Jego wiernych.

Kończąc rozważania, pragnę zauważyć, że rzeczywista liczba świętych (a nie tylko tych kanonizowanych, objawio-

70 Константин Каварнос, Значение новых мучеников..., dz.cyt., c. $10-11$. nych świadomości Kościoła) nie jest znana człowiekowi, a jedynie Bogu. Ponieważ imiona wielu świętych pozostają nieznane, Kościół prawosławny wspomina ich (wraz z tymi znanymi) podczas święta Wszystkich Świętych, obchodzonego w pierwszą niedzielę po Pięćdziesiątnicy. Wtedy, zatem, wspominani są również nieznani nam $\mathrm{z}$ imienia nowomęczennicy bałkańscy. Być może kiedyś niektórzy spośród nich zostaną wysławieni przez Kościół, będą wskazywać drogę żyjącym, oświetlając ją nie swoim światłem, lecz Chrystusowym, światłem Boskiej Miłości. Dlatego też głęboki sens ma modlitewna prośba, którą nasz Kościół kieruje do wszystkich świętych, zarówno tych znanych, jak i nieznanych: „O, wielcy nasi krewni, imienni i bezimienni, objawieni i nieobjawieni, którzyście dosięgli niebiańskiego Syjonu i od Boga chwałę wielką przyjęliście, pocieszenia dla nas w smutkach wypraszajcie..."

71 Nabożeństwo ku czci wszystkich świętych, którzy zajaśnieli na ziemi ruskiej, pieśń 9, kanon 2, troparion 6, суt. za: К.Е. Скурат, Святость Pycu, т. 4, Яхрома 2011, с. 712.

\section{Bibliografia}

Św. Augustyn, Wybór mów (kazania świąteczne i okolicznościowe), tł. J. Jaworski, wstęp i oprac. E. Stranula, Warszawa 1973.

C. Cavarnos, The Significance of the New Martyrs in the Life of the Orthodox Church, Center for Traditionalist Orthodox Studies, Etna 1992.

J. Charkiewicz, Kanonizacja świętych $w$ prawosławiu, Warszawa 2014.

J. Charkiewicz, Nowi męczennicy serbscy, „Cerkiewny Wiestnik”, 2001, nr 3, s. 38-44.

J. Charkiewicz, Prawosławie w Chinach, „Arche. Wiadomości Bractwa", 1999, nr 3, s. 30-33.

J. Charkiewicz, Typologia świętych $w$ Kościele prawosławnym: próba systematyki, „Elpis”, 2009, XI (XXII), 19-20 (32-33), s. 323-380.

J. Charkiewicz, E. Kocój, Rumuńscy święci, Hajnówka 2012.

Św. Jan Chryzostom, Katechezy chrzcielne (Homilie katechetyczne do tych, którzy maja być oświeceni, oraz do neofitów), przeł. ks. W. Kania, wstęp i oprac. ks. M. Starowieyski, Lublin 1993.

N. Constas, „To Sleep, Perchance to Dream”: The Middle State of Souls in Patristic and Byzantine Literature, „Dumbarton Oaks Papers", 2001, nr 55, ed. A.-M. Talbot, s. 96-104.

D. Constantelos, The 'Neomartyrs' as Evidence for Methods and Motives Leading to Conversion and Martyrdom in the Ottoman Empire, "Greek Orthodox Theological Review", 1978, No 23, p. 216-234.

D. Constantelos, Altruistic Suicide or Altruistic Martyrdom? Christian Greek orthodox Neomartyrs: A Case Study, "Archives of Suicide Research", 2004, vol. 8, No 1.

Św. Cyprian, Pisma, t. 1, Traktaty, przekł. i komentarz J. Czuj, Poznań 1937.

H. Delehaye, Melanges d'hagiographie grecque et latine, Bruxelles 1966.

P. Evdokimov, Prawosławie, przekł. ks. J. Klinger, Warszawa 1986.
A. Kawecka, Święci, świętość, błogosławieni w starych słowiańskich księgach liturgicznych i hagiograficznych, [w:] Święci i świętość u korzeni tworzenia się kultury narodów słowiańskich, red. W. Stępniak-Minczewa, Z.J. Kijas OFM Conv, Kraków 2000.

K. Leśniewski, Kanonizacja świętych $w$ tradycji Rosyjskiego Kościoła Prawosławnego, „Roczniki Teologiczne. Teologia Ekumeniczna”, t. LV, z. 7, Lublin 2008, s. 89-108.

Męczennicy, oprac., wstęp i wybór tekstów E. Wipszycka i ks. M. Starowieyski, OŻ, t. 9, Kraków 1991.

A. i M. Mironowicz, Święty Antoni Supraski, Białystok 2014.

New Martyrs on the Turkish Yoke, trans. by Leonidas J. Papadopoulos, Georgia Lizardos and others, Washington 1985.

Początki kultu relikwii na Zachodzie, pod red. R. Wiśniewskiego, Warszawa 2011.

A. Rigo, N. Russel, Neomartyrs of the greek calendar, "Sobornost, incorporating Eastern Churches Review", 1983, No 5, p. 3662.

G. Skowrońska-Płaczynta, O kategoriach świętych w prawosławiu $i$ ekwiwalentach ich rosyjskich nazw w języku polskim, [w:] Z problemów przekładu i stosunków międzyjęzykowych, pod red. T. Żeberek i T. Boruckiego, Kraków 2002, s. 173-189.

Stanford J. Shaw, History of the Ottoman empire and modern Turkey, vols. 1-2, Cambridge 1976.

N. Vaporis, The Price of Faith: Some Reflections on Nicodemos Hagiorites and His Struggle against Islam, Together with a Translation of the 'Introduction' to His 'New Martyrologion', "Greek Orthodox Theological Review", 1978, No 23, p. 185215.

N. M. Vaporis, Witness for Christ. Orthodox Christian Neomartyrs of the Otoman Period 1437-1860, Crestwood 2000.

K. Ware, Kościót prawosławny, przekł. ks. W. Misijuk, Białystok 2002. 
M. Wysocki, ks., Model doskonałego chrześcijanina w pismach św. Cypriana z Kartaginy, „Vox Patrum” 30 (2010), t. 55.

Архимандрит Трифон, О положении христиан в мусульманском государстве согласно шариату, http://www. pravoslavie-i-islam.ru/trifon.htm [dostęp 19.01.2015].

Архимандрит Фома (Петар), Свящзенномученик Николай Хашех, перевела с арабского Надежда Семенова, http:// www.pravoslavie.ru/orthodoxchurches/41541.htm [dostęp 19.01.2015].

Афонский патерик, или Жизнеописание святых, на Св. Абонской горе просиявших, Москва 1897, т. 2.

Будь верен до смерти. Судьбы Православия в Османской империи XV-XX вв., Москва 2005.

Е. Е. Голубинский, История канонизации святых Русской Церкви, Москва 1903.

Свт. Григорий Нисский, Творения, т. 8, Москва 1871.

Движение колливадов, http://www.pravoslavie.ru/archiv/kollibades.htm [dostęp 17.01.2015].

Прот. Димитрий Поздняев, Церковь на крови мучеников, http://www.chinese.orthodoxy.ru/russian/kb3/Martyrs2. htm [dostęp 3.01.2014].

Жития святых составленные на Святой Горе Абон. Синакcapb, т. VI, июль-август, Москва 2011.

К. Иванова, (энциклопедическая статья) Житейная литература, [в:] Православная энциклопедия, т. 19, Москва 2008.

Иеромонах Илия (Читтерио), Преподобньй Никодим Святогореи - учитель духовной жизни и маяк Церкви, перевод Ирина Волкова, „Православная община” 2000, № 60.
Свт. Иоанн Златоуст, Творения, т. 3, Санкт-Петербург 1897, c. 896.

К. Каварнос, Значение новых мучеников в жизни Правоставной Церкви, „Православная жизнь”, № 2 (590), февраль 1999.

А. В. Муравьёв, (энциклопедическая статья) Житейная литература, [в:] Православная энииклопедия, т. 19, Москва 2008.

Новомученики балканские, Москва 2000.

Собрание документов Русской Православной Церкви, т. 2, ч. 1. Деятельность Русской Православной Церкви, Москва 2014.

И. И. Соколов, Константинопольская иерковь. Опьт исторического исследования, т. 1, Санкт-Петербург 1904.

П. А. Соловьев, свящ., Христианские мученики, пострадавшие на Востоке со времени завоевания Константинопотя турками, СПб. 1862.

К. Е. Скурат, Святость Руси, т. 4, Яхрома 2011.

К. Тер-Давтян, (энциклопедическая статья) Житейная литература, [в:] Православная энииклопедия, т. 19, Москва 2008.

Е. В. Ткачев, (энциклопедическая статья) Канонизация, [в:] Православная энииклопедия, т. 30, Москва 2012.

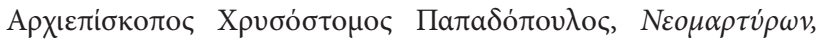
AӨńvaı 1970.

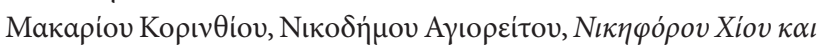

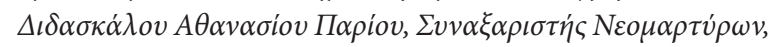

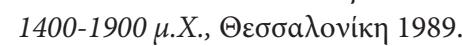

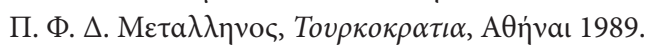

Rozmiar artykułu: 1,1 arkusza wydawniczego 
ISSN 1508-7719

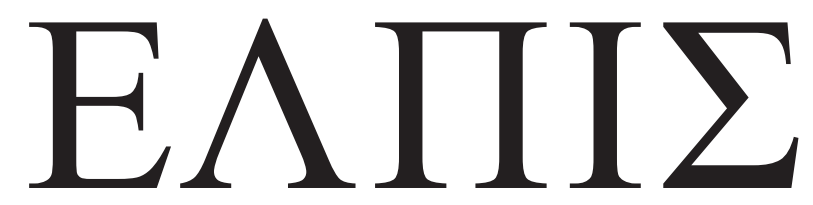

CZASOPISMO TEOLOGICZNE KATEDRY TEOLOGII PRAWOSŁAWNEJ UNIWERSYTETU W BIAŁYMSTOKU

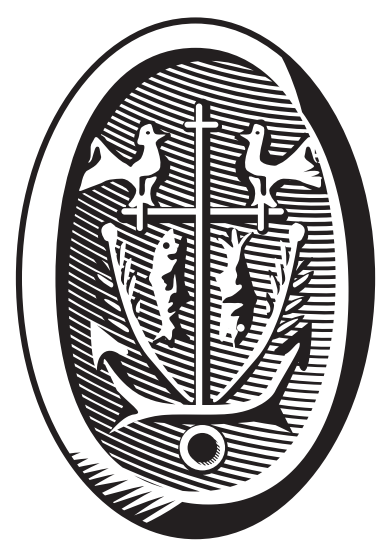

ADRES REDAKCJI

15-097 Białystok, ul. M. Skłodowskiej-Curie 14 tel. 85 745-77-80, e-mail: redakcja@elpis.edu.pl www.elpis.uwb.edu.pl 